\title{
THE EFFECT OF ACTIVE LEARNING STRATEGY USING THE THREE STAGE OF FISHBOWL DECISION TYPES ON THE RESULT OF HISTORY LEARNING
}

\author{
Wahidul Basri, Zafri, Senja Aisya ${ }^{1}$
}

\begin{abstract}
The ability of students of SMAN 1 Bukittinggi in studying history, especially in interpreting the facts are still low. To overcome these problems the writer try to applied active learning strategies Three Stage of Fishbowl Decision types (TSFD). The purpose of this study is to determine the effect of the use of active learning strategies on learning outcomes of TSFD type in the result of studying history, especially in the interpretation of historical facts. This research is experimental with Pretest-Posttest Control Group Design research. The results showed that active learning strategies of the type of TSFD were good for interpreting historical fact. However, after further analysis based on the pattern of growth or movement changes, in the process of active learning strategies of TSFD type was suitable to be applied. Furthermore, for the facts are based on royal topics of TSFD strategy that has turned out as good for the material that is repetition. Based on the analysis conducted it is believed that active learning strategies of TSFD type is better used on materials that complete require repetition.
\end{abstract}

Keywords: Active learning of Three Stage Fishbowl Decision types.

${ }^{1}$ Wahidul Basri, Zafri, Senja Aisya is a lecturer in the Department of History at Universitas Negeri Padang (UNP). For academic interest, the author can be contacted through the office address: Kampus IKIP Air Tawar, Padang, Sumatera Barat. 


\section{Introduction}

National education system set up to prepare qualified human resources. Producing qualified human resources is through following the progress of science developed at this time. Accordingly, the 20 Constitution in 2003 section 3 of the National Education System states that, education is a conscious and deliberate effort to create an atmosphere of learning and the learning process so that learners are actively developing their potentials to have the spiritual religious strength, self-control, personality, intelligence, noble character, and skills needed by the society, nation and state.

Basically, the goal of national education is to develop the ability of students to be able to think critically, logically, meticulous, creative, effective and innovative so that these goals through learning outcomes can be achieved. Learning outcomes can be achieved through optimal learning process. In this case Sudjana (2002:22) states that the study results is the ability of the students after experiencing the learning process. On the other hand Bloom (in Djaafar, 2001:83) divides the learning outcomes into three domains, namely: 1) cognitive (knowledge), include: knowledge or memory, comprehension, application, analysis, synthesis and evaluation. 2) affective the result of the ability of affective learning (attitude), and 3) psychomotor skills.

Today, one of the learning outcomes of the highlights is the result of studying history. History is one of the compulsory subjects taught in senior high school/SMA. The subject is a branch of science that examines the origins and development and the role of the community in the past. Associated with education in elementary school to high school, knowledge of the past contains the values of wisdom that can be used to train the intellectuals, forming attitudes, character and personality of the students.

In BSNP (2006:1) it explaines that the purpose of teaching history, are: 1) building awareness of the students to the importance of time and place that is a process of the past, present, and future, 2) developing critical power train learners, 3) fostering appreciation and respect to the historical heritage of learners, 4) fostering students to have understanding of the process of formation of the nation of Indonesia, 5) increasing self-awareness in the students as part of the Indonesian nation that can be implemented in various areas of life.

From the purpose above it shows that, in principle, the teaching of history has several characteristics. These characteristics are thinking in the motion of the process of change and thinking logically the three dimensions of time (past, present, and future). The students should be able to think critically to the process of historical change and motion in the three-dimensional logical thinking time. Critical thinking in the historical material can be realized in the form of questions. In this case there are at least six questions that you can ask to be answered by a person as a sign that she has the ability to think critically: what, when, who, where, and how.

Another goal of the study is to develop learner understanding to history learners. The understanding by Sudjana (2002:201) as the ability to think that higher than just knowing. So, understand is a person's ability to express the meaning is learned, interpreted, and then predicted the outcome of what he sees.

Silverius (1991:40-44) says that person who is aware if has three capabilities. 
Capabilities are: 1) to ability describes is the ability of students to illustrate a historical fact, 2) the ability to distinguish is the ability of students to compare a concept in the historical material, and 3) The ability to explain is the ability of students to explain a causal relationship in historical material.

If the observed learning process in the field of history is not corresponded with the principles of learning, history lesson objectives cannot be fully achieved. Based on the results of interviews with the writers of history teachers in SMAN 1 Bukittinggi on September 10, 2012, it was noted that the value of daily tests for the class XI of IPS in the historical subjects was still under the minimum completeness criteria. From the class XI of IPS 2 with 54 students, who completed the study to only 24 people. This shows that there were still many students who have not completed the study of history yet.

From the observations made 12 of September 2012 at SMAN 1 Bukittinggi, showed that during the learning process the teacher asks the students, relating to the interpretation of historical facts. From the 27 students of class XI of IPS 1 is only 11 students who were trying to find and answer that question. From the while respondents, there were only 5 people who answered the question correctly. It could be concluded that the students' ability to interpret the facts of history were still low.

The low learning outcomes that impact on the teaching history the failure of can be caused by several factors. According Slameto (2003:54) the factors influence learning outcomes can be classified into two factors, internal and external factors.

School is one of the factors that can influence learning outcomes. School factors include teaching methods, curriculum, teacher and student relations, student and student relations, school buildings, facilities and infrastructure, school discipline, and others. According to Usman (2006:9) playing is an important role in teacher and student learning outcomes. In studying, the teachers roles are as facilitators, motivator, and evaluators of learning. Teacher as facilitator must have the ability to apply good learning model that can improve student learning outcomes.

In particular the low learning outcomes are also caused by the lack of suitable learning model, usually dominated by the teacher learning and instructional strategies that are less varied. This can lead to boredom for students and they tend to be passive.

From some factors above, the fact that many are found in the field is the lack of variety in teaching teachers. In general, teachers are still using conventional learning strategies that are teacher centered where the teacher is the only source in the information center, while students record the teacher's explanation and do chores.

In learning to be teacher centered, teachers only share knowledge or dictate material without providing an opportunity for students to explore and understand the material itself. This can cause students to be passive, not creative, and critical. In teaching history teacher centered strategies that are not able to train students in interpreting the facts, because at the time of the learning process of students just listen and accept that is the material presented by the teacher so that they become lazy to read the learning materials and do not aware of the facthistorical fact, as it is found at SMAN 1 Bukittinggi.

To overcome these problems, the authors believe that a suitable learning strategies for students able to interpret the 
historical facts is an active learning strategy of Three Stage Fishbowl Decision type. This strategy the teacher has the opportunity to put forward questions and for the students can interpret the facts. Questions can also be given to inquire motion patterns of history and historical materials that include facts, concepts, and principles.

Based on the above issues and phenomena, the authors try to apply the Active Learning Strategies of Three Stage Fishbowl Decision type at SMAN 1 Bukittinggi. Implementation of the research was limited to see the learning outcomes of students in interpreting historical facts into concepts and principles (causal relationship). Research conducted at SMAN 1 Bukittinggi. Meanwhile the objectives are to determine the effect of the application of active learning strategies of Three Stage Fishbowl Decision type on the result of learning history of students at SMA N 1 Bukittinggi.

\section{Research Methods}

Thisresearchisanexperimentalresearch. In this research, the learning processes were performed in two classes: experimental and control classes. In the experimental class the strategy of active learning of Three-Stage Fishbow Decision type was applied and in the control class was learning teacher centered. Population was student of class XI of IPS at SMAN 1 Bukittinggi of 2012/2013 that consist of 2 classes and all the population as sample (total sampling).

Variables in this research consist of: 1) IndependentVariables(X)isanactivelearning strategies of the Three-Stage Fishbowl Decision type and dependent variable $(\mathrm{Y})$ is the result of learning interpretation of facts.
Research designed using formula Control Group Pretest-Posttest Design. At first both groups were given pretests $\left(\mathrm{O}_{1}\right.$ and $\left.\mathrm{O}_{3}\right)$. Both groups had the same thing except the treatment (X). Experimental class performed the learning process as much as four times with the active learning strategy of Three Stage Fishbowl Decision type. Meanwhile the control class by the number of meetings and the same number of students applied teacher centered learning. After both groups are they treated equally, get or posttest measurements (O2 and O4). Simply designs of this research are as follows:

\section{$\mathrm{O} 1 \mathrm{X} \quad \mathrm{O} 2$ \\ O3 $\mathrm{O}_{4}$}

In general, the research procedure can be divided into three stages, namely the preparation phase, theimplementation phase and the completion phase. The instrument used to collect data in this research is the achievement test. Tests are used to measure that learning outcomes is an achievement test in the form of multiple choice with four options.

Data analysis techniques include: 1) descriptive analysis to describe the state of the data as it is collected from the sample that has been presented in frequency distribution tables, and then calculated the standard deviation. Treatment variables are described using active learning strategies TSFD type (X1) teacher centered learning. 2) inferential analysis which aims to determine whether the research hypothesis is accepted or rejected. To test the hypothesis $t$-test is applied. Before performing the t-test is necessary to test the data analysis requirements of normality and homogeneity of the test.

Hypothesis testing aims to determine whether the hypothesis is accepted or rejected. To test the hypothesis first test 
the normality and homogeneity of the tests. T-test formula used is:

$$
\begin{gathered}
\mathrm{t}=\bar{X}_{1}-\bar{X}_{2} \\
\sqrt{\begin{array}{c}
\left(n_{1}-1\right) S_{1}^{2}+\left(n_{2}-1\right) S_{2}^{2} \\
n_{1}+n_{2}-2
\end{array}}\left(\frac{1}{n_{1}}+\frac{1}{n_{2}}\right)
\end{gathered}
$$

\section{Results and Discussion}

The results of learning history can be seen through the tests conducted on the two classes of the experimental and control classes. The experimental class grade of XI IPS 1 class with 26 students and the number of control is class XI of IPS 2 with the same number is 26 students. Sample data processed by the experimental class and the control classes, are 26 student of experimental class and 26 student of the control class.

From data analysis of the pretest value the average value of the experimental classes was better than the control classes, but the variance was control class better than experiment class. This can be seen in the following table.

Table 11.1.

\section{Comparison value of Pretest between the experimental class and control class}

\begin{tabular}{|l|l|l|l|l|}
\hline Class & $\mathbf{N}$ & Average & Variance & $\begin{array}{l}\text { Deviation } \\
\text { Standard }\end{array}$ \\
\hline Experimental & 26 & 4,81 & 11,6 & 3,41 \\
\hline Control & 26 & 3,54 & 7,38 & 2,72 \\
\hline
\end{tabular}

From Posttest values of the data analysis, it known that the average value of the experimental classes is better than the control class, but the variance of the control class is better than of the experimental class. This can be seen in the following table.
Table 11.2.

\section{Comparison value of Postest} between the experimental class and control class

\begin{tabular}{|l|l|l|l|l|}
\hline Class & $\mathbf{N}$ & $\overline{\boldsymbol{X}}$ & $\mathbf{S}^{\mathbf{2}}$ & $\begin{array}{l}\text { Primary } \\
\text { School }\end{array}$ \\
\hline Experimental & 26 & 8,88 & 20,66 & 4,55 \\
\hline Control & 26 & 6,27 & 10,60 & 3,26 \\
\hline
\end{tabular}

From the analysis of the data, the posttest was about the establishment of the Islamic empire, the average value of the experimental class is better than the control class, but for variance, the control class is better than the experimental class. This can be seen in Table 9.3 below.

Table 11.3.

Comparison value of the experimental class and the control class with indicators facts interpreted on the material establishment of Islamic kingdoms in Indonesia

\begin{tabular}{|l|l|l|l|l|}
\hline Class & $\mathbf{N}$ & \multicolumn{1}{|c|}{$\overline{\boldsymbol{X}}$} & $\mathbf{S}^{\mathbf{2}}$ & $\begin{array}{l}\text { Primary } \\
\text { School }\end{array}$ \\
\hline Experimental & 26 & 2,96 & 3,80 & 1,95 \\
\hline Control & 26 & 2,00 & 1,62 & 1,27 \\
\hline
\end{tabular}

The result of Posttest data analysis about the development of Islamic kingdoms, the average value of the experimental classes are better than the control class, but for variance control class is better than the experimental class. This can be seen in the following table.

Table 11.4.

Comparison value of the experimental and the control classes with indicators facts interpreted on materials development of Islamic kingdoms in Indonesia

\begin{tabular}{|l|l|l|l|l|}
\hline Class & $\mathbf{N}$ & \multicolumn{1}{|c|}{$\overline{\boldsymbol{X}}$} & $\mathbf{S}^{\mathbf{2}}$ & $\begin{array}{l}\text { Primary } \\
\text { School }\end{array}$ \\
\hline Experimental & 26 & 2,38 & 1,61 & 1,27 \\
\hline Control & 26 & 1,69 & 1,38 & 1,17 \\
\hline
\end{tabular}


From the data analysis posttest questions in the Islamic kingdoms, the average value of the experimental class is better than the control class, but for variance, control class is better than the experimental class. This can be seen in the following.

Table 11.5.

\section{Comparison value of the experimental and control classes with indicators facts interpreted on material the Islamic kingdoms in Indonesia}

\begin{tabular}{|l|l|l|l|l|}
\hline Class & $\mathbf{N}$ & \multicolumn{1}{|c|}{$\overline{\boldsymbol{X}}$} & $\mathbf{S}^{\mathbf{2}}$ & $\begin{array}{l}\text { Primary } \\
\text { School }\end{array}$ \\
\hline Experimental & 26 & 1,46 & 0,98 & 0,99 \\
\hline Control & 26 & 1,31 & 0,92 & 0,96 \\
\hline
\end{tabular}

The result of Posttest data analysis about the collapse of Islamic empires, the average value of the experimental class is better than the control class, but for variance, the control class is better than the experimental class. This can be seen in the following.

Table 11.6.

Comparison value of the experimental and the control class with indicators facts interpreted on material: collapse of Islamic kingdoms in Indonesia

\begin{tabular}{|l|l|l|l|l|}
\hline Class & $\mathbf{N}$ & \multicolumn{1}{|c|}{} & $\mathbf{S}^{\mathbf{2}}$ & $\begin{array}{l}\text { Primary } \\
\text { School }\end{array}$ \\
\hline Experimental & 26 & 1,46 & 0,98 & 0,99 \\
\hline Control & 26 & 1,31 & 0,92 & 0,96 \\
\hline
\end{tabular}

Based on the analysis of all the data posttest above, it can be concluded that the average value of the experimental class is better than the control class, but for variance control class is better than of the experimental class. Through the average value obtained from the experimental and control classes, it can be seen that the changes are always the same, namely the experimental class is better than the control class.

After applied the Test different pretest, apparently early ability graders experiment with initial grade control capability. This is evident from the results of the t-test showed that $t_{\text {obtained }}<t_{\text {table, }}$ is to 1.49 whereas $t_{\text {table }}$ is 2.01. Because $t_{\text {obtained }}<t_{\text {table, }}$, the hypothesis test scores pretest value is not processed and the posttest scores were processed.

At the time the normality and homogeneity test result of the data are normally distributed and homogeneous, it means that there is no significant difference between the experimental class and the control class. For the calculation of normality in the control class obtained $l_{\text {obtained }}=0.0566$ meanwhile $l_{\text {table }}=0.173$ the experimental class obtained lobtained at 0.0401 and lable at 0.173 for the second it means that the data is normal. It means that there is no difference in the two variance data, it is evident from the calculations of $F_{\text {obtained }}<F_{\text {table }}$ where $F_{\text {obtained }}$ $=1,95$ and $F_{\text {table }}=1,96$ and the sample class is homogeneous. Since both the data are normally distributed and their variance were homogeneous then to find the hypothesis, t-test was used. T-test was performed to see the achievement of the experimental classes which were better than the control class.

Hypothesis test is used in the calculation formula of the t-test in order to get the value $t_{\text {obtained }}=2.39$ and $t_{\text {table }}=2.01$ with $t_{\text {obtained }}>$ table, thus $\mathrm{H}_{\mathrm{o}}$ is rejected. With the rejection $\mathrm{H}_{\mathrm{o}}$ means there is significant influence implementation of active learning strategies of Three-Stage Fishbowl Decision type on students' ability to interpret the facts in the teaching of history.

After calculating the t-test as a whole, it can be concluded that $\mathrm{H}_{\mathrm{o}}$ is rejected, in other words, $\mathrm{H}_{1}$ is accepted. However, after 
testing the hypothesis based on the pattern of development of the kingdom which consists of the standing, growing, retreat and collapse of the Islamic kingdoms, is to stand up, expand, and collapse t-test results differ, in other words $\mathrm{H}_{1}$ accepted. As for the retreat, t-test performed with similar results to other words $\mathrm{H}_{\mathrm{o}}$ which are accepted. This can be seen in the following table.

Table 11.7.

\section{Comparison of calculations T-test between of the experimental class and control class based on patterns of development}

\begin{tabular}{|l|l|l|l|l|}
\hline Component & $\begin{array}{l}\bar{X}, \text { primary } \\
\text { school of } \\
\text { experimental } \\
\text { class }\end{array}$ & $\begin{array}{l}\bar{X} \text {,primary } \\
\text { school of } \\
\text { control } \\
\text { class }\end{array}$ & $\begin{array}{l}\text { Calculations } \\
\text { of t-test }\end{array}$ & Information \\
\hline Standing & 2,96 & 2,00 & 2,09 & Different \\
& 1,95 & 1,27 & 2,01 & \\
\hline Growing & 2,38 & 1,69 & 2,09 & Different \\
& 1,27 & 1,71 & 2,01 & \\
\hline Backward & 1,46 & 1,31 & 0,63 & Same \\
& 0,99 & 0,96 & 2,01 & \\
\hline Collapsing & 2,04 & 1,27 & 2,02 & Different \\
& 1,43 & 1,04 & 2,01 & \\
\hline
\end{tabular}

From the above analysis it can be concluded that the experimental and control classes to stand development patterns, evolve, collapse of $H_{1}$ are accepted. This is due to the study of history has been tought since elementary school until high school, that the students are used to study the history of material changes in the motion pattern consisting of standing, growing, and collapsed. Meanwhile backward motion patterns of $H_{\mathrm{o}}$ accepted. This happened because in general the subject matter of history about the retreat and collapse patterns are combined. More specifically, the researchers at the time of the motion pattern of teaching history in the classroom also do not distinguish between the motion and the motion collapse backwards. This makes the child cannot distinguish between a royalretreat with the collapse of an empire.
However, based on the type of Islamic kingdoms, for the kingdom of Samudra Pasai, Malacca, Demak, Banten, Mataram, and Makassar, show differences, whereas for the royal kingdom of Aceh and Maluku kingdom did not have different significant. For more details, it can be seem the following table:

Table 11.8.

Comparison of calculations T-test of the experimental class and control class based on kingdoms

\begin{tabular}{|c|c|c|c|c|}
\hline Component & $\begin{array}{l}\bar{X} \text {, primary } \\
\text { school of } \\
\text { experimental } \\
\text { class }\end{array}$ & $\begin{array}{l}\bar{X}, \text { control class } \\
\text { of primary } \\
\text { school }\end{array}$ & $\begin{array}{l}\text { Calculations } \\
\text { of t-test }\end{array}$ & Information \\
\hline \multirow{2}{*}{$\begin{array}{l}\text { Kingdom of } \\
\text { samudra pasai }\end{array}$} & 0,46 & 0,15 & 3,10 & \multirow[t]{2}{*}{ Different } \\
\hline & 0,51 & 0,37 & 2,01 & \\
\hline \multirow{2}{*}{$\begin{array}{l}\text { Kingdom of } \\
\text { Malaka }\end{array}$} & 1,38 & 0,88 & 2,06 & \multirow[t]{2}{*}{ Different } \\
\hline & 0,98 & 0,82 & 2,01 & \\
\hline \multirow{2}{*}{$\begin{array}{l}\text { Kingdom of } \\
\text { Aceh }\end{array}$} & 1,65 & 1,38 & 0,19 & \multirow[t]{2}{*}{ No different } \\
\hline & 1,30 & 1,14 & 2,01 & \\
\hline \multirow{2}{*}{$\begin{array}{l}\text { Kingdom of } \\
\text { Banten }\end{array}$} & 2,27 & 1,38 & 2,11 & \multirow[t]{2}{*}{ Different } \\
\hline & 1,69 & 1,39 & 2,01 & \\
\hline \multirow{2}{*}{$\begin{array}{l}\text { Kingdom of } \\
\text { Demak }\end{array}$} & 0,46 & 0,19 & 2,70 & \multirow[t]{2}{*}{ Different } \\
\hline & 0,51 & 0,40 & 2,01 & \\
\hline \multirow{2}{*}{$\begin{array}{l}\text { Kingdom of } \\
\text { Mataram }\end{array}$} & 1,27 & 0,73 & 2,25 & \multirow[t]{2}{*}{ Different } \\
\hline & 0,87 & 0,87 & 2,01 & \\
\hline \multirow{2}{*}{$\begin{array}{l}\text { Kingdom of } \\
\text { makasar }\end{array}$} & 0,65 & 0,27 & 2,71 & \multirow[t]{2}{*}{ Different } \\
\hline & 0,49 & 0,45 & 2,01 & \\
\hline \multirow{2}{*}{$\begin{array}{l}\text { Kingdom of } \\
\text { Maluku }\end{array}$} & 0,73 & 1,27 & $-2,7$ & \multirow[t]{2}{*}{ No different } \\
\hline & 0,72 & 0,72 & 2,01 & \\
\hline
\end{tabular}

Based on the above analysis it can be concluded that the Islamic empire of 8, 6 of them (the kingdom of Samudra Pasai, Malacca, Demak, Banten, Mataram, and Makassar) are different and the hypothesis is accepted. This is because the material is a common material that is often discussed and studied by students from junior high school until high school, in addition to the student handbook subject matter is also described in detailAs for the 2 royal(royalkingdom of Aceh and Maluku) experimental and control class capabilities are the same and the hypothesis is rejected, it is because the students have textbooks (history book for high school social studies class XI with the author is I Wayan Badrika) the discussion for the royal 
kingdom of Aceh and Maluku is very limited and the teacher is in the presentation does not provide perfect information.

According to Bruner in Dahar (2011:79) discovery learning of cognitive skills is to train students to find and solve the problem. So that, students can learn actively through finding answers to these given questions. Bruner considers that the study findings are the result of the nicest and produce knowledge that is really meaningful. In active learning, the strategy of Three-Stage Fishbowl Decision type is the teacher presents three interrelated questions to each group. One of the questions that the students are being trained to interpret the historical facts presented, so they are trained discover concepts based on existing facts. Thus, study can be meaningful because of the study findings from the questions given.

Based on the previous discussion of the following, it may be implied. First, the discussion of aspects of the development pattern (standing, growing, and collapses) with theactivelearningstrategyofTSFDtype the two differ onces between experimental and the control class capabilities, the hypothesis is accepted. Thus, the active learning strategies of TSFD tyfe is used to students' develop the ability of interpreting facts based development pattern (standing, growing, and collapse). So that to be better, the teachers should multiply the source of the Islamic kingdoms and they have a lot to give the questions on the interpretation of the facts in order student have better understanding.

Second, the discussion of aspects of the development pattern (backwards), experimental class capability equal with control class hypothesis is rejected. So that active learning strategies of TSFD type is not suitable for student's ability to interpret the facts in the pattern of development (backwards) this is due to the material for the development of backward pattern is rarely discussed in textbooks owned by students so that they cannot find the concept through the facts presented by teacher. To resolve the matter, a teacher must have a lot more teaching materials about the royal pullback pattern of development in the learning process so that the teachers can explain and distinguish between patterns of backward movement.

Third, the discussion of the material on Islamic kingdoms, there is a difference between the ability of the experimental and control classes or hypothesis is accepted. Thus, the type of active learning strategies of TSFD type used for the students' ability to interpret facts based on materials royal kingdom. For this to be sustained and become better, teachers and students must have reading material even more, but it also provides more teacher questions about the interpretation of the facts at the time of such strategies.

Fourth, the discussion of the material on the kingdom of Aceh and Maluku, there are similarities between the experimental and the control class capabilities or hypothesis is rejected. So that active learning strategies are not suitable for the TSFD type on the student's ability to interpret the material facts in the kingdom of Aceh and Maluku. To resolve the matter, a teacher must have a lot more teaching material about the royal material so that the learning process when the questions given to the students, they can easily find the concept of the facts presented. 


\section{Conclusion}

Based on the data analysis and the above discussion it can be concluded that: 1) active learning strategy of Three Stage Fishbowl Decision types is good to be used to interpret the facts based on the pattern of development for a given material that is a common. 2) active learning strategy of the Three Stage Fishbowl Decision types are difficult to interpret because of the fact based on the pattern of development, the material was limited and the delivery of the content material about the pattern and collapse pattern of development are not separated. 3) active learning strategy of Three Stage Fishbowl Decision types is good to interpret the facts in the kingdom, if the material have regular repetition and study, 4) active learning strategy of the Three Stage Fishbowl Decision types are difficult to interpret the facts by royal difficulty to interpret if the material discussed are limited.

\section{REFERENCES}

Ankersmit. (1987). Refleksi Tentang Sejarah. Jakarta: Gramedia Arikunto, S. (2009).Dasar-Dasar Evaluasi Pendidikan. Jakarta: Bumi Aksara

Asmani, J. M. (2011). PAKEM "Pembelajaran Aktif, Kreatif, Efektif, dan Menyenangkan”. Jogjakarta: DIVA press

Dahar, R. W. (2011). Teori-Teori Belajar dan Pembelajaran. Bandung: Erlangga

Gottschalk, L. (1986). Mengerti Sejarah. Jakarta: Universitas Indonesia (UI Press)

Hamalik, O. (1990). Psikologi Belajar Mengajar. Bandung: Sinar Baru Algesindo
Hasan, S. H. (1997). Pengembangan Teori dan Metodologi Serta Orientasi Pendidikan Sejarah: Kurikulum dan Buku Teks Sejarah. Jakarta: Depdikbud.

Hasan, S. H. (2008). Pengembangan Berpikir Kritis dalam Pembelajaran Sejarah. Makalah pada Seminar IKAHIMSI, 8 April 2008 di UPI, Bandung. Kuntowijoyo. (2005). Pengantar Ilmu Sejarah. Yogyakarta: Bentang

Kamarga, H. (2002). Belajar Sejarah Melalui e-learning: Alternatif Mengakses Sumber Informasi Kesejarahan. Jakarta: PT Intimedia

Nana, S. (2002). Dasar-Dasar Proses Belajar Mengajar. Bandung: Sinar Baru Algesindo

Nana. Sudjana. (2004). Penilaian Hasil Proses Belajar Mengajar.Bandung: Sinar Baru Algesindo.

Permen Diknas No. 41 Tahun 2007. Tentang Standar Proses Untuk Satuan Pendidikan Dasar dan Menengah.

Silberman, M. (2007). Active Learning "101 Strategi Pembelajaran Aktif". Yogyakarta: Pustaka Insan Madani

Slameto. (2003). Belajar dan FaktorFaktor yang Mempengaruhinya. Jakarta: Rineka Cipta

Soewarso. (2000). Cara-Cara Penyampaian Pendidikan Sejarah Untuk Membangkitkan Minat Peserta Didik Mempelajari Sejarah Bangsanya. Departemen Pendidikan Nasional

Suke, S. (1991). Evaluasi Hasil Belajar dan Umpan Balik. Jakarta: Gramedia Widiasarana Indonesia

Usman, U. (2006). Menjadi Guru Profesional. Bandung: Remaja Rosda Karya. 
WAHIDUL BASRI, ZAFRI \& SENJA AISYA,

The Effect of the Aplication of Active Learning Strategy on the Three Stages Decision Types on the Result of History Learning

Weiner, R.G. (1995). History: teaching and methods. ED 387402 (Eric Document Reproduction service).

Widja, I. G. (1990). Dasar-dasar Pengembangan Strategi Serta Metode Pengajaran Sejarah. Edisi Pertama. Jakarta: Depdikbud.

Widja, I. G. (1991). Pendidikan Sejarah dan Tantangan Masa Depan. Singaraja: FKIP Universitas Udayana.

Wiriaatmadja, R. (1996). Pendidikan Sejarah di Indonesia. Bandung: Historia Utama Press.
Wiriaatmadja, R. (1998). Simposium Pengajaran Sejarah: Landasan Filosofis Kurikulum Pengajaran Sejarah (SMU) Tantangan dan Harapan. Jakarta Depdikbud.

Wiriaatmadja, R. (2002). Pendidikan Sejarah di Indonesia. Bandung: Historia Utama Press.

Wiriaatmadja, R. (2005). Metode Penelitian Tindakan Kelas. Bandung: PT Remaja Rosdakarya 